Andre Veenendaal, Tanya Bondarouk*

\title{
Perceptions of HRM and their effect on dimensions of innovative work behaviour: Evidence from a manufacturing firm ${ }^{* *}$
}

Research has shown that employees' innovative work behaviour is important for the competitive advantage of organizations. However, the question of how this innovative work behaviour can be stimulated remains unanswered. The purpose of this paper is to test empirically the effect of perceptions of four high-commitment HR practices on three dimensions of innovative work behaviour by production workers. Disentangling three dimensions of innovative work behaviour makes it conceptually possible to determine how perceived HRM can stimulate three different behavioural types linked to idea generation, idea championing, and idea application. The results of a survey among 328 workers in a Dutch manufacturing company show that four perceived HR practices (supportive supervision, training and development, information sharing, and compensation) have an effect on all three dimensions of innovative work behaviour. Overall, positively perceived supportive supervision was found to be the most beneficial practice for innovative work behaviour.

Key words: perceived HR practices, (dimension of) innovative work behaviour, individual innovation-(JEL: J24, M12, O31)

* Andre Veenendaal, University of Twente. E-mail: a.a.r.veenendaal@utwente.nl. Tanya Bondarouk, University of Twente. E-mail: t.bondarouk@utwente.nl.

** Article received: July 29, 2014

Revised version accepted after double blind review: May 4, 2015.

management revue, 26(2), 138-160

ISSN (print) 0935-9915, ISSN (internet) 1861-9908
DOI 10.1688/mrev-2015-02-Veenendaal (C) Rainer Hampp Verlag, www.Hampp-Verlag.de 


\section{Introduction}

For several decades, individual innovative performance has been considered as one of the most important organizational drivers in dealing with rapid changes, such as globalization, and emerging new technologies. Research has shown that organizational innovation performance is enhanced by individual innovative performance, referred to from the behavioural perspective as innovative work behaviour (IWB) (e.g. De Jong \& Den Hartog, 2007; Høyrup, 2010; Janssen, 2000; Scott \& Bruce, 1994). The existing literature has accumulated rich conceptual and empirical knowledge on a variety of factors influencing IWB, including the organizational climate (e.g. Scott \& Bruce, 1994), job design (e.g. Farr, 1990), transformational leadership (e.g. Basu \& Green, 1997), commitment (e.g. Thompson \& Heron, 2006), trust (e.g. Carmeli \& Spreitzer, 2009), problem-solving style (e.g. Scott \& Bruce, 1994), and role expectations (e.g. Shalley \& Gilson, 2004). Recently, scholars have started largely conceptual discussions about stimulating the innovation potential of "ordinary" workers and their participation in innovation, so-called employee-driven innovation (Høyrup, 2010; Kesting \& Ulhøi, 2010), and claimed that, if properly supported, even "routine" workers can show strongly innovative behaviour (Evans \& Waite, 2010) and that the innovative work behaviour can be made "visible, recognized, and exploited to the benefit of both the firm and its employees" (Kesting \& Ulhøi, 2010, p. 66). This is particularly apparent in manufacturing firms, in which the need for innovation is high and production workers have the skills and knowledge required to contribute directly and strongly to organizational innovation performance (Høyrup, 2010; Laursen \& Foss, 2003). Several discrete managerial practices have been considered as drivers of innovative behaviour by employees, including rewards, decision structures, and time and resource support (Kesting \& Ulhøi, 2010).

Surprisingly, few attempts have been made to evaluate empirically the impact of managerial support practices on IWB. Empirical research is scarce, and what is available does not reach beyond supporting the value of human resource management in general. Human resource (HR) practices have been found to play an important role in general at the organizational level enhancing organizational innovation performance (e.g. Beugelsdijk, 2008; Shipton, West, Dawson, Birdi, \& Patterson., 2006; De Leede \& Looise, 2005; Jiménez-Jiménez \& Sanz-Valle, 2005), and at the individual level in stimulating organizational innovation by enhancing the creativity of individual employees (e.g. Dul, Ceylan, \& Jaspers, 2011; Mumford, 2000). For example, Jiang, Wang, and Zhao (2012) found that several HR practices affect employees' creativity, such as hiring, selection, and rewards. However, the studies did not empirically test the particular effect of specific HR practices and generally maintained a conceptual focus (e.g. Galbraith, 1982; Gupta \& Singhal, 1993; Kanter, 1988; Mumford, 2000; Shalley \& Gilson, 2004).

At this point, we should clarify this paper's position. We depart from the idea that the formulation and interpretation of organizational issues (here - innovation performance issues) is based on people's perceptions of organizational processes (here human resources management practices) (Hodgkinson, 1997). Organizational members' perceptions of HR practices influence their actions and attitudes in response to 
changes in the HRM processes. Further, social cognitive research has shown that people act on the basis of their perceptions and interpretations, and in doing so they enact particular social realities through giving them meaning (Bartunek \& Moch, 1994; Fyske \& Taylor, 1991; Goodhew, Cammock, \& Hamilton, 2005; Weick, Sutcliffe \& Obstfeld, 2005). Based on the way in which people perceptually filter external information, their attitudinal and behavioural responses to that information may differ, and the natural information processing mechanisms of individuals influence the way in which they perceive situations. Different studies have supported the notion that individuals bring different motivations (Locke \& Latham, 1990), past experiences (Rousseau, 2001), demographic backgrounds (Cox, 1993), values (Meglino \& Ravlin, 1998), personalities (Hough \& Schneider, 1996), and attitudes (Brief, 1998), which all influence their ways of interpreting and reacting to organizational experiences. Another, closely related, research stream builds on HR practices being communication mechanisms that give signals of the organization to employees, that employees can understand and interpret these signals differently (Bowen \& Ostroff, 2004; Nishii, Lepak, \& Schneider, 2008; Sonnenberg, Van Zijderveld, \& Brinks, 2014). Interpretations may include assumptions, knowledge, and expectations expressed symbolically through language, visual images, metaphors, and stories that represent subjective data, and they act as a tool to facilitate decision making, problem solving, and negotiating within the context of organizational intervention (Cossette \& Audet, 1992). Perceptions and interpretations have been linked with cognitive frames, which in their turn have been shown to be related to managers' performance (Jenkins \& Johnson, 1997; Laukkanen, 1994), decision making (Axelrod, 1976), performance appraisal (Gioia, Donnellon, \& Sims, 1989), strategic behaviour (Dutton \& Jackson, 1987), strategy formulation (Hodgkinson \& Johnson, 1994), exercise of power (Bartunek \& Ringuest, 1989), leadership (Lord \& Maher, 1991), and organizational performance (Thomas, Clark, \& Gioia, 1993).

Some HR practices have been studied from the perceptual point of view. For example, within compensation it has been found that younger workers without children might hold more favourable opinions towards receiving minimal extra benefits but above-market pay levels, while older employees might view receiving comprehensive benefits more favourably (Milkovich \& Newman, 1999). Judge and Cable (1997) concluded that individuals who rate highly in conscientiousness are more attracted to organizations with cultures characterized by a need for achievement. These differences in the personal valuation of benefits and cultures, developed through the goals and preferences of an individual, can lead to varying extents to which people are satisfied with, and react to, certain measures and messages within organizations. Guzzo and Noonan (1994) concluded that the very same set of HR practices can be perceived positively by some employees but not by others, depending on the level of perceived fit between those practices and employees' individual values, personality, goals, and schematic expectations.

Therefore, the main contribution of this paper is to test empirically the effect of perceptions of specific HR practices on the innovative work behaviour of "ordinary" employees (Kesting \& Ulhøi, 2001), specifically in the manufacturing industry. We view IWB as consisting of the generation of ideas, including the identification of op- 
portunities, and then the championing and application of these ideas (Janssen, 2000). This approach rests on the idea that IWB is more than idea generation - the creative process of individuals. This has been extensively studied (e.g. Dul et al., 2011; Shalley \& Gilson, 2004), but how the generated ideas are implemented has been explored less. Although earlier research has identified multiple dimensions to innovative work behaviour, most studies have reported findings suggesting that innovative work behaviour is a one-dimensional variable based on a lack of distinctiveness between the proposed dimensions (De Jong \& Den Hartog, 2010; Janssen, 2000; Kleysen \& Street, 2001; Scott \& Bruce, 1994). Nevertheless, we seek a multidimensional perspective on IWB: conceptually, we claim that, by considering innovative work behaviour as a multidimensional concept, research is likely to identify a more nuanced impact of perceived HR practices on the various dimensions of IWB. For example, employees who show behaviour associated with idea generation may not necessarily show high levels of championing behaviours. The question that remains is then how to support the best components of IWB (Kleysen \& Street, 2001).

Following the logic above, the central question of this paper concerns the extent to which perceptions of HR practices stimulate innovative work behaviour. We first provide a theoretical explanation for, and build hypotheses on, the relationship between perceptions of HR practices and innovative work behaviour. After this, we describe the methods used to test the developed hypotheses. Finally, we present and discuss the results and the implications of our findings.

\section{Theory and hypothesis development}

Innovative work behaviour is defined as employee behaviour to create, introduce, and apply new ideas intentionally within a work role, a group, or an organization that are beneficial to performance (Janssen, 2000, p. 288). As such, several innovation dimensions can be identified within the concept of innovative work behaviour (see Figure 1). It starts with the generation of ideas. While the terms idea generation and creativity are often used interchangeably, we opt for "idea generation" to stay close to the innovative work behaviour literature (De Jong \& Den Hartog, 2007; Høyrup, 2010; Janssen, 2000; Scott \& Bruce, 1994). Within this idea generation dimension, employees recognize problems and opportunities and seek new ideas as solutions. Mumford (2000, p. 316) described idea generation as "a free-flowing activity where application, implication, and consequences are identified and then shaped through refinement into a new idea or set of ideas". The subsequent, second dimension is idea championing. Here, the idea is promoted throughout the organization to find support for further development. Finding support involves building coalitions of potential allies - individuals who provide the necessary power to move the idea into practice - by expressing enthusiasm and confidence about success, being persistent, and involving the right people (De Jong \& Den Hartog, 2010; Galbraith, 1982; Janssen, 2000; Kanter, 1988). These could be managers, members of other departments, such as R\&D, or immediate coworkers. Idea championing is all about finding support for the ideas generated and involving key organizational members in the ideas of employees. The aim of the third dimension, idea application, is to incorporate the ideas that were generated and promoted into the daily business (Kleysen \& Street, 2001) and to realize those ideas that can 
be experienced and applied within the work role, group, or organization (Janssen, 2000; Kanter, 1988). The final two dimensions, idea championing and idea application, are often jointly labelled as implementation.

Figure 1: Innovation as a three-dimensional process

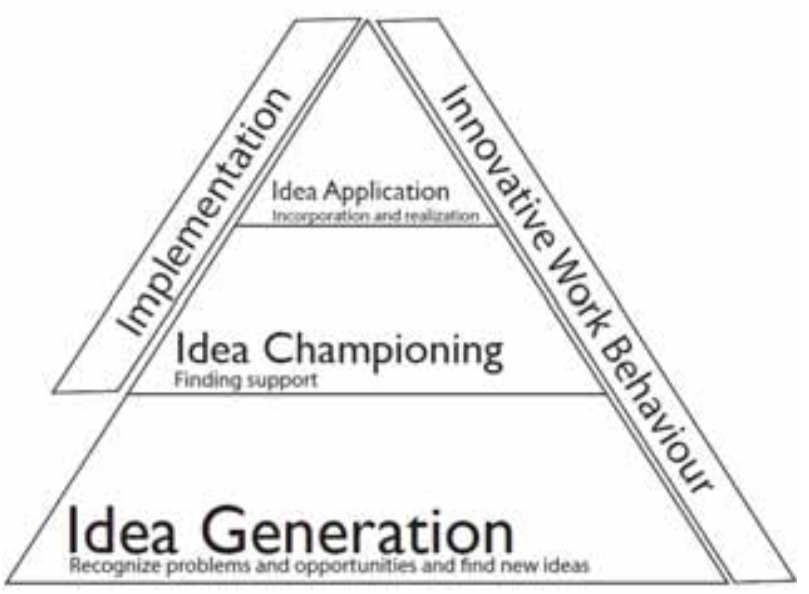

Previous research on innovative work behaviour has mainly considered it to be a single dimension consisting of multiple sets of behaviours (e.g. De Jong \& Den Hartog, 2010; Janssen, 2000, 2004; Scott \& Bruce, 1994). IWB as a single dimension can be seen as a container for several behavioural sets. These sets of behaviours correspond to our dimensions of idea generation, idea championing, and idea application. By conceptualizing IWB in terms of multiple sets of behaviours, a nuanced picture appears of individuals' contributions to organizational outcomes. For example, the generation of ideas alone does not assure the implementation of those ideas, because new ideas may induce uncertainty, which could result in resistance to change (Baer, 2012; West, 2002). Further, the three dimensions (idea generation, idea championing, and idea application) require different types of work, different personal characteristics in employees, and different behaviours (De Jong \& Den Hartog, 2010; Kleysen \& Street, 2001; Scott \& Bruce, 1994). As Scott and Bruce (1994, p. 582) argued, innovation is a dynamic process "characterized by discontinuous activities" rather than being made up of discrete dimensions.

Arguably, employees are likely to show behaviours corresponding to different combinations of the dimensions identified above (Scott \& Bruce, 1994). In other words, individual employees on the work floor can behave in ways that correspond to all three dimensions or perhaps excel in one behaviour over the others.

\section{$H R$ practices to stimulate innovative work behaviour}

For work floor employees, innovative work behaviours are discretionary in that they prioritize the behaviours prescribed for fulfilling their primary tasks. Discretionary behaviours can be elicited by HR practices geared towards achieving high commitment from employees or, as McClean and Collins (2011, p. 342) stated, "high commitment HR practices create a mutually beneficial environment whereby firms in- 
vest in their employees and induce them to reciprocate that investment by exerting higher levels of discretionary behaviors". If the aim of HR practices within organizations is to increase employee commitment, then well-designed HR practices will send signals to employees through giving a strong perception of organizational support (Bowen \& Ostroff, 2004). In line with social exchange theory, it is logical to assume that employees will reciprocate by giving something of value to the organization (Blau, 1964). If the organization's signals are perceived as valuable to employees, they will be willing to reciprocate with a high level of commitment (Masterson, 2001). For organizations, employees' discretionary behaviours are valuable, surpassing the prescribed behaviours that cover their day-to-day activities.

Taylor and Greve (2006) found that commitment is needed for idea generation, although they did not offer insights into the HR practices that would enhance commitment. In a study in Spanish manufacturing firms, Gonzalez-Alvarez and NietoAntolin (2007) found that high-commitment HR practices are positively related to innovation. In order to stimulate innovative work behaviour, it has been suggested that HR practices should focus on the individual level (Dul et al., 2011).

There is little agreement on a complete list of those HR practices that enhance high commitment (e.g. Delery \& Doty, 1996; McClean \& Collins, 2011), although Collins and Smith (2006, p. 544) suggested that high-commitment HR practices generally focus on "creating internal labor markets and assessing fit to the company", employee motivation directed towards group and organizational performance indicators, establishing a long-term orientation, team building, and developing firmspecific knowledge. Although there is no consensus on a list of high-commitment HR practices, some practices are more associated with high commitment than others (Collins \& Smith, 2006; Kwon, Bae, \& Lawler, 2010). For this study, we have selected those HR practices that are considered to be "employee management activities" (Boselie, Dietz, \& Boon, 2005) - practices that are commonly expected to support commitment and are relevant to production workers: supportive supervision (e.g. Arthur, 1994; Boselie, Hesselink, Paauwe, \& van der Wiele, 2001; McClean \& Collins, 2011; Wallace, 1995), training and development (e.g. Boselie et al., 2001, 2005; Gould-Williams \& Davies, 2005; McClean \& Collins, 2011; Way, 2002), information sharing (e.g. Boselie et al., 2001, 2005; Gould-Williams \& Davies, 2005; Way, 2002), and compensation (e.g. Boselie et al., 2001, 2005; Gould-Williams \& Davies, 2005; McClean \& Collins, 2011; Way, 2002).

In several studies, appropriate recruitment and selection are reported as being essential for high levels of commitment (McClean \& Collins, 2011). However, we have excluded this aspect from the set of HR practices in this study since recruitment tends to have a low priority within the manufacturing industry. Before the economic crisis, manufacturing firms were experiencing a tight labour market in the sense of there being a lack of skilled production workers, and the attention was focused on retaining workers rather than acquiring new employees (Blatter, Muehlemann, \& Schenker, 2012; Hiltrop, 1996; Remery, Henkens, Schippers, \& Ekamper, 2003). Now, during the economic downturn, manufacturing firms are not seeking to recruit but rather to retain their current workers for after the crisis (Picchio \& Van Ours, 2013). 
High-commitment HR practices aim to motivate employees to deliver value through engaging in discretionary behaviours by "aligning their interests with those of the organizations and creating a mutually reinforcing high-investment employeremployee relationship" (Collins \& Smith, 2006, p. 546). Different employees will have different interests and therefore variation is expected in experiences of HR practices and employee outcomes. We will focus on employees' perceptions of HR practices, given that variations in these perceptions of HR practices, rather than the precise design and implementation of HR practices, will be likely to lead to variations in the (discretionary) behaviours shown (Wright \& Nishii, 2006). In the remainder of this paper, when we talk about HR practices, we refer to employees' perceptions of these HR practices.

\section{Supervisory support}

As HR practices are management practices that aim to increase employees' knowledge, skills, abilities (KSAs), and motivation, as well as empowering these employees to leverage their KSAs to deliver value (Combs, Liu, Hall, \& Kitchen, 2006), we consider the support given by supervisors to be HR practices. The role of supervisors is considered important in stimulating employees to perform and execute tasks that are in line with the organizational goals (Arthur, 1994; Kanter, 1988; Shalley \& Gilson, 2004). If employees interpret their supervision as supportive, they feel encouraged to give something in return. Reciprocation towards the supervisor is beneficial in terms of producing behaviours that exceed the formal job description (Rhoades Shanock \& Eisenberger, 2006).

In this respect, idea generation is likely to occur if supervisors are supportive (Amabile, Conti, Coon, Lazenby, \& Herron, 1996; De Jong \& Den Hartog, 2007; Kanter, 1988; Shalley \& Gilson, 2004). For example, Frese, Teng, and Wijnen (1999) found that the more supervisors supported employees, the more ideas the latter contributed to their organization's suggestion programmes. Supportive supervisors are those who show concern for employees' feelings and needs, stimulate them to communicate their worries, and provide positive, largely informational feedback (Oldham \& Cummings, 1996). As Basu and Green (1997) found in their study of 225 supervisor-employee dyads in a Fortune 500 firm, employees are more likely to generate, support, and apply ideas by engaging in unconventional behaviour if they are confident that they will not be penalized for doing so. By receiving support, employees feel stimulated to assert their ideas, take risks, and show innovative work behaviour (Basu \& Green, 1997).

On this basis, we hypothesize:

H1: Employees who experience supportive supervision from their line manager will show behaviour associated with (1a) idea generation, (1b) idea championing, and (1c) idea application.

\section{Training and development}

Training has a positive impact on the skills and knowledge of employees and on employee behaviour, employee motivation, and employee output (Way, 2002). Training designed to enhance creativity is found to be positively related to the level 
of employees' idea generation (e.g. Basadur, Wakabayashi, \& Graen, 1990; Scott, Leritz, \& Mumford, 2004). For example, Scott et al. (2004) found in their metaanalysis of 70 studies, containing 4,210 participants in creativity training, a strong average effect size of this type of training with a Cohen's delta of 0.68 . Not only do specific training activities geared towards creativity and innovation contribute, but also the extent to which employees feel that they are given relevant opportunities to develop in their own job and career (Gupta \& Singhal, 1993). As Amabile et al. (1996, p. 1161) put it, perceptions of the "adequacy of resources may affect people psychologically by leading to beliefs about the intrinsic value of the projects that they have undertaken". In line with this, training and its availability are viewed as a resource, and the perceived opportunities for training affect employees' levels of idea generation (Amabile et al., 1996). Training enhances employees' sets of knowledge and skills. With an enhanced skill set, employees are more aware of the various alternatives and opportunities and feel more secure in experimenting and trying out new things (Shalley \& Gilson, 2004). By receiving relevant opportunities for training, employees are encouraged to come up with new ideas and to advance them further (Jiang, Wang, \& Zhao, 2012; Shalley \& Gilson, 2004). As Axtell, Holman, Unsworth, Wall, Waterson, \& Harrington (2000) argued, opportunities to take on a wider, more skilled, and more autonomous role at work are important for generating ideas, rather than for implementing ideas. As such, we hypothesize the following:

H2: Employees who perceive that their organization facilitates training and development will show behaviour associated with idea generation.

\section{Information sharing}

Goal setting in itself is found to have a positive impact on idea generation (Locke \& Latham, 2002; Shalley, 1995). As such, employees need to be aware of what their organization wants to achieve, and this is governed by the extent to which it shares information. In order to generate ideas, employees should know what the organization is striving for and what it stands for (Shalley \& Gilson, 2004). Information sharing is described in terms of employees' perceptions of the extent to which they are informed about the organization's overall goals and achievements, as well as its norms and values. Information sharing contributes to innovative work behaviour in two ways. First, if employees are made aware of what the company stands for and what its goals are, they know what to expect and what behaviour is expected of them. Second, by sharing information with them, employees gain self-worth and perceptions of importance to the company, which lead to reciprocation. It is likely that employees will reciprocate in terms of beneficial discretionary behaviour, engaging in behaviour that fits the mission and vision of the organization. This is in line with the change management literature, which suggests that receiving information about a change is beneficial in terms of the employees' receptiveness towards the change (Wanberg \& Banas, 2000). Although there is little empirical evidence to support the idea that information sharing affects innovative work behaviours, several conceptual studies suggest this (e.g. Arad, Hanson, \& Schneider, 1997; Hiltrop, 1996; Shalley \& Gilson, 2004). Therefore, we propose the following hypothesis: 
H3: Employees who perceive their organization as sharing information will show behaviour associated with (3a) idea generation, (3b) idea championing, and (3c) idea application.

\section{Compensation}

Jiang et al. (2012, p. 6) argued that employees' rewards affect their "motivation to be creative, offer new ideas and be willing to experiment with new behaviors". Some scholars have studied the effect of compensation on innovation by focusing on specific compensation systems, such as those geared towards incentivizing innovation (e.g. Jiang et al., 2012; Zhou, Zhang, \& Montoro-Sanchez, 2011) or offering performance-based pay (e.g. Beugelsdijk, 2008). Although these systems result in employees experiencing financial incentives to behave according to the criteria underlying the system, such as creating new products, bringing in new ideas, or improving productivity, such systems also produce perverse effects. By considering whether employees feel fairly compensated, instead of looking at the type of compensation system that an organization has, we bypass these perverse effects. We argue that innovative work behaviour is promoted when employees feel fairly treated, given that in such a state employees feel a strong sense of belonging and identification with their organization and the accompanying higher commitment to the organization (Masterson, 2001). Further, compensation is what organizations pay employees in exchange for their labour in which regular task-specific behaviours are demonstrated (Folger \& Konovsky, 1989). Extra efforts or helpful behaviours are elicited by distributive justice (Masterson, 2001). Employees who perceive the compensation as fair in terms of distributed justice consider it as a bonus to their "contracted-for reward” (Amabile, Hennessey, \& Grossman, 1986; Amabile et al., 1996). On this basis, we propose the following hypothesis:

H4: Employees who perceive their compensation to be fair will show more behaviour associated with (4a) idea generation, (4b) idea championing, and (4c) idea application.

However, arguments can also be made for a competing hypothesis: if people are compensated fairly but see no possibility for growth, either pay- or career-wise, they are unlikely to feel a need to reciprocate towards the organization. Furthermore, employees who experience fair compensation may feel less inclined to be visible than employees who perceive a lack of distributive justice, who might therefore feel the need to demonstrate positive attitudes and behaviours towards the organization in order to gain a bonus or other reward (Folger, 1993). Rewards are considered to be detrimental to idea generation if tasks are designed too narrowly and leave little room for exploration and play (Amabile \& Cheek, 1988; Eisenberger, Armeli, \& Pretz, 1998).

Therefore, we can hypothesize the following:

H4: Employees who perceive their compensation to be fair will show less behaviour associated with (4d) idea generation, (4e) idea championing, and (4f) idea application. 
The hypothesized relationships are visualized in the research model shown in Figure 2.

Figure 2: Hypothesized relationships between HR practices and IWB dimensions

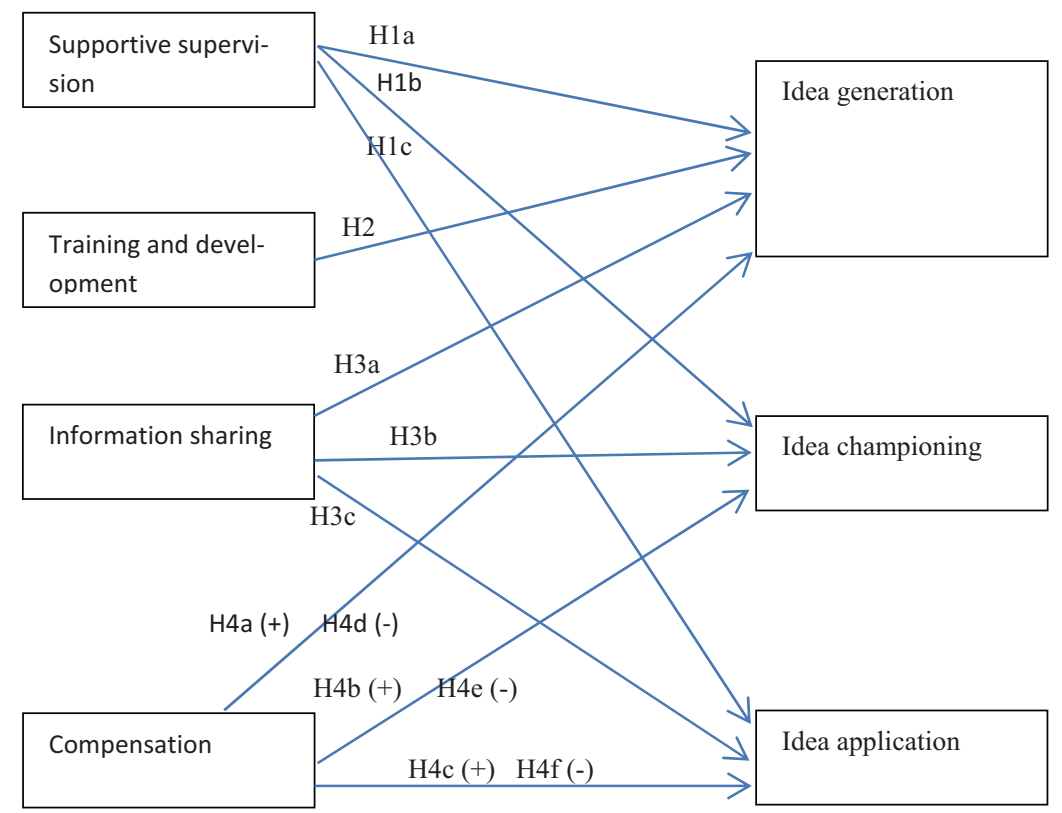

\section{Method}

We collected data for our study in June-July 2011 within a Dutch manufacturing company employing about 1700 people, of whom 1100 worked in the production and engineering departments. The manufacturing firm's core product is not generally known for its innovativeness and has a fixed function. If innovations are to be expected, they will be process innovations, material innovations, or design innovations. In line with ideas from the employee-driven innovation concept, we targeted respondents who were production workers on the work floor. Although production workers did not have formal job tasks dedicated to innovation, they were able to show innovative work behaviour and thereby contribute directly to the innovative performance of the organization. Data were collected by means of a written questionnaire. To minimize our interference with the production process and productivity these questionnaires were distributed as follows: 40 randomly selected production supervisors were given 10 questionnaires each and asked to distribute them to 10 production workers whom they supervised. We asked supervisors to distribute the questionnaires randomly, however we cannot exclude the idea of a convenience sample here: given that our data collection needed to minimize hindrance in the production process and maximize the cooperation of respondents and the company, it is possible that supervisors selected the respondents on availability or capacity. The employees received an internal communication (mail or oral presentation) from their line managers, and they were assured that their participation was voluntary. Anonymity of the responses was assured. 
The first author was present at the company to answer questions and clarify the procedure. Of these 400 production workers, 328 returned the questionnaire, giving a response rate of 82 per cent.

\section{Measures}

\section{HR practices}

We drew upon the measures of high-commitment HR practices proposed by Boselie et al. (2001) and measured each of them in terms of the perceptions of the extent to which a certain HR practice took place within the organization. In addition, items measuring supportive supervision were adapted from Yukl, Wall, and Lepsinger (1990). We used a five-point Likert scale, ranging from $1=$ "totally disagree" to $5=$ "totally agree". We adapted perceptions of four HR practices: "compensation" (three items, e.g. "As far as I know our salaries are as high or even better than those of comparable organizations"), "training and development" (three items, e.g. "I get sufficient opportunities to attend skills training to improve my current position"), "information sharing" (four items, e.g. "I am well informed on the vision and mission of the company"), and "supportive supervision" (four items, for example "My supervisor supports me when I want to improve things"). All the scales were found to be reliable, with Cronbach's alphas of 0.70 (compensation), 0.79 (perceived training and development), 0.82 (information sharing), and 0.85 (supportive supervision).

\section{Innovative work behaviour}

Innovative work behaviour was measured in terms of the extent to which employees perceive that they generate and introduce useful ideas (Dul et al., 2011). These authors argued that individual employees are best placed to rate their own innovative work behaviour because "they are aware of the subtle things they do in their jobs" and because others do not have full insight into the "thoughts and activities of other individuals" (Dul et al., 2011, p. 723). The three identified dimensions of innovative work behaviour are measured by adopting items from De Jong and Den Hartog (2010) and Kleysen and Street (2001). All the items were scored on a five-point Likert scale with possible answers ranging from $1=$ "never" to $5=$ "very often". Six questions addressed idea generation - three items adopted from Kleysen and Street (2001) and three items from De Jong and Den Hartog (2010) - an example item being "Do you search out new working methods, techniques, or instruments?" Another two items concerned idea championing, adopted from De Jong and Den Hartog (2010), for example "Do you attempt to convince people to support an innovative idea?" The final three items on innovative work behaviour dealt with idea application, for which the items were also adopted from De Jong and Den Hartog (2010), including "Do you put effort into the development of new things?" The Cronbach's alphas were between .72 and .95 , indicating that the scales were reliable.

\section{Control variables}

The tenure, age, and education level of a workforce may reflect the characteristics of an organization and the way in which human and other resources are deployed, and they may influence IWB. Therefore, we included these variables as control variables to measure any effects. Tenure was measured as the number of years employed in the 
organization. Age was measured in the number of years at the point in time of filling in the questionnaire. The education level achieved was categorized $(1=$ primary school; 2 = secondary school; 3 = lower vocational education; $4=$ intermediate vocational education; 5 = university).

\section{Analyses}

Before testing the hypotheses, we first performed analyses to examine the measurement errors. To minimize measurement errors in the form of common method variance, we carried out a Harman's single-factor test. A principal component analysis with no rotation was conducted on all the items. The results of the analysis showed that no single factor dominated and the largest factor explained 25.6 per cent of the variance, allowing us to conclude that the data did not suffer from common method variance (Podsakoff \& Organ, 1986). Multicollinearity issues were similarly ruled out as the correlations of the predictor variables were between 0.00 and 0.54 , well below the threshold of 0.75 (Ashford \& Tsui, 1991). The values of the variance inflation factor (VIF) associated with the predictors were between 1.23 and 1.87, again within acceptable limits (Hair, Black, Babin, \& Anderson, 2010; O’Brien, 2007).

An exploratory factor analysis was performed on all the multiple-scale items to determine item retention (e.g. Kuvaas, 2008). Furthermore, a confirmatory factor analysis was carried out to determine whether the IWB dimensions are distinct from each other. Regression analysis was used to test the hypotheses.

\section{Results}

Principal component analysis with varimax rotation was performed on all the multiple-scale items to determine item retention (e.g. Kuvaas, 2008). This analysis showed, after dropping two items from the idea generation dimension because of low factor loadings, that the innovative work behaviour items loaded onto three factors. Aware that previous research had found a lack of distinctiveness between the IWB dimensions, we carried out a confirmatory factor analysis (e.g. De Jong \& Den Hartog, 2010; Janssen, 2000; Kleysen \& Street, 2001). First, we tested a model with nine items loading onto three factors that built on our theory section and on the exploratory factor analysis. The model was specified as a second-order CFA model, with innovative work behaviour as the first-order factor. Next, we tested a model with the selected nine items loading onto a single factor. The analyses (see Table 1) indicated that the onefactor model was a bad fit, with the chi-square to degrees of freedom ratio above 5.0, the GFI, NFI, and CFI indices of fit all below 0.90, and an RMSEA above 0.08 (Hair et al., 2010). Conversely, the three-factor model achieved at least a good fit using all the criteria; the chi-square to degrees of freedom ratio was below 3.0, the GFI, NFI, and CFI indices of fit were all above 0.95 , and the RMSEA was acceptable, below 0.08 (Hair et al., 2010). This analysis thus supports our decision to view innovative work behaviour as having three distinct dimensions.

Table 1: Fit indices for one- and three-factor models of IWB

\begin{tabular}{llllll}
\hline Model & X2/df & GFI & CFI & NFI & RMSEA \\
One-factor model & 7.897 & 0.802 & 0.828 & 0.809 & 0.181 \\
Three-factor model & 1.945 & 0.955 & 0.979 & 0.958 & 0.067 \\
\hline
\end{tabular}


Table 2 provides an overview of the descriptive statistics, correlations, and Cronbach's alphas. The means of the three dimensions of innovative work behaviour show that employees scored above neutral in terms of creative behaviour, but showed significantly lower scores on the implementation dimensions (paired samples T-test, $\mathrm{p}<0.01$ ). Employees scored themselves below neutral on behaviours corresponding to the two implementation dimensions of idea championing and idea application. This significant difference confirms the view that individuals can demonstrate behaviour that corresponds much more to one dimension of innovative work behaviour, rather than being spread across all the dimensions. In this firm, production workers assessed themselves as idea generators rather than as implementers, champions, or appliers.

Receiving supportive supervision was positively correlated with all three innovative work behaviour dimensions (idea generation: $\mathrm{r}=0.30, \mathrm{p}<0.01$; idea championing: $\mathrm{r}=0.34, \mathrm{p}<0.01$; idea application: $\mathrm{r}=0.30, \mathrm{p}<0.01)$. Information sharing was also positively correlated with the three dimensions $(\mathrm{r}=0.15, \mathrm{p}<0.01 ; \mathrm{r}=0.14, \mathrm{p}<0.01$; and $\mathrm{r}=0.20, \mathrm{p}<0.01$, respectively). Training and development was positively correlated with the idea application dimension $(\mathrm{r}=0.12, \mathrm{p}<0.05)$ and compensation was negatively related to idea generation.

Table 2: Means, standard deviations, correlations, and Cronbach's alphas

\begin{tabular}{|c|c|c|c|c|c|c|c|c|c|c|c|c|}
\hline Variables & Mean & SD & 1 & 2 & 3 & 4 & 5 & 6 & 7 & 8 & 9 & 10 \\
\hline 1. Tenure & 13.17 & 10.49 & & & & & & & & & & \\
\hline 2. Age & 40.38 & 10.63 & $0.75^{* *}$ & & & & & & & & & \\
\hline $\begin{array}{l}\text { 3. Educational } \\
\text { level }\end{array}$ & 2.38 & 0.83 & $-0.17^{* *}$ & -0.08 & & & & & & & & \\
\hline $\begin{array}{l}\text { 4. Supportive } \\
\text { supervision }\end{array}$ & 3.58 & 0.73 & 0.05 & 0.01 & 0.02 & $(0.84)$ & & & & & & \\
\hline $\begin{array}{l}\text { 5. Training \& } \\
\text { development }\end{array}$ & 3.57 & 0.79 & $-0.19^{* *}$ & $-0.18^{* *}$ & 0.03 & $0.43^{*+*}$ & $(0.80)$ & & & & & \\
\hline $\begin{array}{l}\text { 6. Information } \\
\text { sharing }\end{array}$ & 3.42 & 0.65 & 0.00 & 0.01 & -0.01 & $0.32^{* *}$ & $0.54^{* *}$ & $(0.78)$ & & & & \\
\hline $\begin{array}{l}\text { 7. Compensati- } \\
\text { on }\end{array}$ & 3.04 & 0.77 & $-0.10^{*}$ & $-0.11^{*}$ & -0.00 & $0.16^{* *}$ & $0.46^{* *}$ & $0.28^{* *}$ & $(0.70)$ & & & \\
\hline $\begin{array}{l}\text { 8. Idea } \\
\text { generation }\end{array}$ & 3.16 & 0.74 & $0.15^{* *}$ & 0.08 & 0.05 & $0.30^{* *}$ & 0.02 & $0.15^{* *}$ & $-0.12^{*}$ & $(0.83)$ & & \\
\hline $\begin{array}{l}\text { 9. Idea } \\
\text { championing }\end{array}$ & 2.59 & 1.04 & $0.21^{* *}$ & 0.07 & 0.00 & $0.34^{* *}$ & 0.04 & $0.14^{* *}$ & -0.03 & $0.63^{+*}$ & $(0.88)$ & \\
\hline $\begin{array}{l}\text { 10. Idea } \\
\text { application }\end{array}$ & 2.71 & 1.03 & $0.14^{* *}$ & 0.08 & -0.01 & $0.30^{* *}$ & $0.12^{*}$ & $0.20^{* *}$ & -0.05 & $0.58^{+*}$ & $0.66^{* *}$ & $(0.86)$ \\
\hline
\end{tabular}

$\mathrm{N}=328$ (one-tailed test).

Cronbach's alpha can be found in the brackets along the diagonal.

* Correlation is significant at $p<0.05$.

${ }^{* *}$ Correlation is significant at $p<0.01$. 
The results of the hierarchical regression analyses are presented in Table 3. The control variables were entered first (models 1,4 , and 7). Secondly, the effects of the perceptions of HR practices on the IWB dimensions were entered but without the effect of the control variables (models 2,5 , and 8). Thirdly, the perceived HR practices were entered into the models with only the control variables (models 3, 6, and 9). Idea generation is the dependent variable for the first three models, idea championing is the dependent variable for models 4,5 , and 6 , and idea application is presented in models 7,8 , and 9 . As the table shows, the overall model fit of the models with only perceived HR practices is better than the overall model fit of the models with both the control variables and the perceived HR practices entered. Therefore, we draw conclusions from the models with only perceived HR practices entered (models 2, 5, and 8), although for reasons of completeness we show the results of the regression analyses of the models into which the control variables and the perceived HR practices were both entered (models 3, 6, and 9). We will report the results in order of the formulated hypotheses. Each hypothesis addresses a perceived HR practice, and we will discuss the perceived HR practices one by one.

Hypothesis 1 predicted a positive relationship between supportive supervision and three dimensions of IWB. Looking at model 2, we can see that supportive supervision has a direct and significant positive effect on idea generation $(p<0.01)$, supporting Hypothesis 1 a. Model 5 shows that supportive supervision has a significant positive effect on idea championing $(\mathrm{p}<0.01)$, supporting Hypothesis $1 \mathrm{~b}$. Supporting Hypothesis $1 \mathrm{c}$, model 8 shows that supportive supervision is significantly related to idea application $(\mathrm{p}<0.01)$.

Hypothesis 2 predicted that training and development are positively related to idea generation. Model 2 suggests that training and development significantly affect idea generation; however, we found a negative effect, with significance at least at the $\mathrm{p}<0.05$ level. As such, Hypothesis 2 is not supported (model 2).

Hypothesis 3 concerns the perceived HR practice of information sharing, predicting that information sharing is positively related to the three dimensions of IWB. Information sharing is found to have a significant effect on idea generation at the $\mathrm{p}<0.05$ level (model 2), offering support to Hypothesis 3 a. Information sharing was not found to be significantly related to idea championing in model 5; therefore, $\mathrm{Hy}$ pothesis $3 \mathrm{~b}$ is not supported. Furthermore, model 8 identified a significant positive effect on idea application $(\mathrm{p}<0.05)$, supporting Hypothesis $3 \mathrm{c}$.

Next, we consider the role of compensation for Hypothesis 4. Model 2 found that this had a significant negative effect on idea generation $(p<0.05)$. Thus, Hypothesis $4 \mathrm{a}$ was rejected and its competing hypothesis, $4 \mathrm{~d}$, was supported. Compensation was marginally significant at the $\mathrm{p}<0.10$ level, negatively affecting idea championing. This offers the suggestion that perhaps Hypothesis $4 \mathrm{~b}$ can be rejected and Hypothesis $4 \mathrm{e}$ supported. Compensation had a significant negative effect on idea application $(\mathrm{p}<0.01)$ (model 8). Thus, Hypothesis $4 \mathrm{c}$ is rejected and Hypothesis $4 \mathrm{f}$ supported. 
Table 3: Results of regression analysis

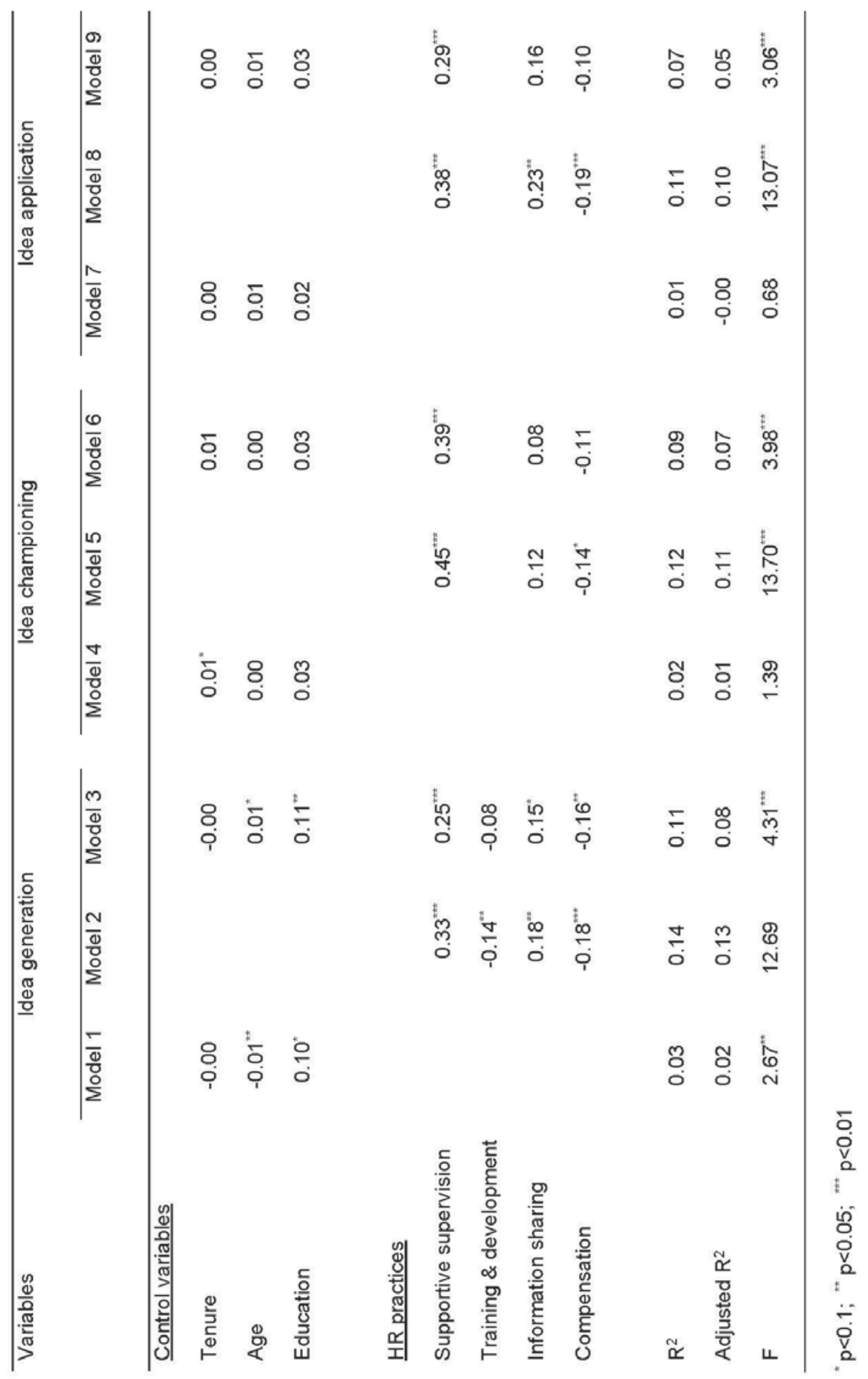




\section{Discussion}

The purpose of this research was to study how perceptions of certain human resource practices affect the three dimensions within innovative work behaviour: idea generation, idea championing, and idea application. Whereas most scholars, when studying innovative work behaviour, treat it conceptually as a single dimension (e.g. Janssen, 2000, 2004; Scott \& Bruce, 1994), we considered innovative work behaviour as multidimensional, identifying three separate dependent dimensions, and explored the effect that perceptions of HR practices have on these three dimensions. We found in our analysis that the three dimensions of innovative work behaviour were indeed separate factors, suggesting that these dimensions are distinct. Therefore, we would suggest that scholarly studies on innovative work behaviour make analytical distinctions between the three dimensions. For practitioners, this provides greater insight into steering the desired dimensions and emphasizing firm-specific aspects of innovative work behaviour. In our survey of a single organization, we found that the respondents scored significantly higher on idea generation than on idea championing and idea application, illustrating that individuals can engage in behaviour that is more closely related to one dimension rather than showing an overall propensity for innovative work behaviour. This finding is in line with scholars who have argued that employees are able to generate ideas by using their domain-specific knowledge and skills, which are acknowledged predictors of idea generation (e.g. Amabile et al., 1996; Perry-Smith, 2006; Shalley \& Gilson, 2004; Woodman, Sawyer, \& Griffin, 1993).

Our research supports the view that innovation processes are complex, entailing a necessary sequential order of ideas (Howell, Shea, \& Higgins, 2005), and that more ideas are generated than supported throughout an organization. In this respect, Stevens and Burley (1997) found that only 300 out of 3,000 generated ideas moved beyond the idea generator's desk. Given that ideas have to be generated before they can be championed, this suggests that idea generation should be found more within organizations than idea championing and idea application (Baer, 2012). Championing and applying ideas are about finding support and incorporating them into daily business, and these require more of idea champions and executors than appropriate behaviour. Howell and Higgins (1990) argued that champions gain support for ideas by advancing financial justifications, arguing that the expected steps are in the same direction as competitors, stressing the beneficial effects of the idea on customers' perceptions of the organization, or linking the idea to key organizational values. This indicates that other skills and knowledge alongside those corresponding to idea championing are required.

The main contribution of this paper is that it has empirically tested the effect of perceived HR practices on three dimensions of innovative work behaviour by "ordinary employees", i.e. production workers, in the manufacturing industry. Four HR practices were conceptually identified of which the perceptions were likely to affect the dimensions of innovative work behaviour: supportive supervision, training and development, information sharing, and compensation. Our findings suggest that behaviours corresponding to the various innovative work behaviour dimensions are fostered by different perceived HR practices. For all three dimensions, supportive supervision has been found to be the most beneficial in terms of innovative work behav- 
iour. The practical implication is that supportive supervision cannot be excessive. However, organizations should be reluctant to provide too many training and development opportunities, especially if they are aiming to gain employees who generate ideas. Information sharing stimulates both idea generation and idea application, but does not boost the championing of ideas. If organizations want to improve their innovative work behaviour, they should be aware of the role that employees' perceptions of fair compensation play. The more they perceive their compensation to be fair, the less they behave creatively, or champion and apply ideas. We did not study rewards as such, rather the fairness of the compensation system, but our findings are consistent with what we know from literature on intrinsic and extrinsic motivation. Rewards imply an extrinsic motivator, and these may imply an attention shift to economic gains and a detrimental effect on proactive innovative behaviour, given that employees may experience reduced autonomy and self-motivation by extrinsic rewards (Deci \& Ryan, 1985; Zhou et al., 2011). Contrary to what we had expected, training and development opportunities were found to have a negative effect on idea generation. The more employees perceive training and development opportunities, the less they show creative behaviour. A possible explanation for this is that employees who experience opportunities are "made too comfortable", suppressing any urges to generate ideas (Shalley \& Gilson, 2004). While employees need to have at least a certain minimum level of resources, such as training opportunities (e.g. Amabile et al., 1996), a lack of resources may stimulate idea generation (Csikszentmihalyi, 1997). It is therefore essential that employees perceive that they have access to a reasonable level of the necessary resources (Drazin, Glynn, \& Karanjian, 1999).

Our research and this paper respond to the call to study specific groups of employees, rather than the full workforce of organizations (e.g. Lepak \& Snell, 1999, 2002). We found that production employees were able to show all three types of innovative work behaviour, but particularly idea generation. Production workers are thus able to contribute to organizational innovativeness. Not surprisingly, most such organizational innovations relate to process innovation since production workers have a more direct influence on the production process than on product specifications (Reichstein \& Salter, 2006).

We now consider the implications of our research findings beyond the direct subject of the study. The research was carried out within a firm that could be considered as pursuing a maximization of efficiency. Characteristic for this company related to their efficiency approach is that they have narrow and relatively stable product-market domains, they seldom need to make major adjustments to their technology, structure, or methods of operation, and they primarily devote their attention to improving the efficiency of their existing operations. These types of organizations are not known for their innovative performance, given the trade-off between innovation and efficiency (Weigelt \& Sarkar, 2012). Our study has shown that even organizations aiming for efficiency are able to encourage innovative work behaviour in their employees. We studied high-commitment HR practices and the effect of the perceptions of these HR practices on innovative work behaviours. Such HR practices aim to stimulate employees to use their discretion in performing and executing tasks so that they are in line with the organizational goals (Arthur, 1994). A question arises regarding the effect that 
control-oriented HR practices, contrary to high-commitment HR practices, have on the various dimensions of innovative work behaviour. Future research would benefit from further exploration of this issue and could also provide more answers on how innovative work behaviour and its specific dimensions are stimulated by HR practices in combination with other factors, such as the organizational climate.

\section{Limitations, practical implications and conclusions}

A possible limitation of our study is that we used self-reported measures of the innovative work behaviours of employees. Although prior research has found strong correlations between self-reporting and supervisor reporting for innovative work behaviours (Axtell et al., 2000; Shalley, Gilson, \& Blum, 2009), future research could include a comparison of self-reporting measures with the perceptions of supervisors of demonstrated behaviours. The understanding would benefit from finding out whether supervisors assess the innovative work behaviours of employees differently and, if so, what effect this has on organizational innovative performance. Any incongruence in the perceptions of supervisors and employees could challenge the anticipated HR practices and lead to a continuous "drift" in the exhibited innovative work behaviour.

Another limitation of this study is that we used cross-sectional data, questioning any implications of causal relationships. This issue has also arisen in other studies within this research field (e.g. Frese et al., 1999; Oldham \& Cummings, 1996). A longitudinal research design is therefore recommended for future research since this would resolve the causality issue and enrich the understanding within the field of human resource practices and their effect on innovative work behaviour. Further, our data were collected from a single manufacturing firm and our results might therefore lack generalizability. However, studying one firm could also be a strength as certain characteristics will be common to all employees, such as the firm's mission and vision, goals, climate, and product lines. Future research could consider a research design involving many organizations spread across different industries.

The results of this study have additional practical implications. The case organization involved was not very innovative in terms of introducing radically new products and, as such, may be representative of many firms. However, such organizations have instruments - HR practices - at their disposal to encourage employees to behave innovatively in order to stimulate organizational innovativeness. Our study provides empirical evidence that organizations are able to send an HRM message to employees to elicit discretionary innovative work behaviours. By addressing dimensions of innovative work behaviour (idea generation, idea championing, and idea application), organizations will be able to identify idea creators, champions, and executors in their workforce and to identify which roles they lack. After recognizing the gaps within the organization, they will be able to acquire the lacking behaviours through HR practices. Our study did not set out to determine the appropriate design of HR practices, but rather to show that employee perceptions of HR practices matter. When designing HR practices, organizations should be aware that the message that these HR practices send should be clear and consistent but that, despite this, it could be perceived differently by employees. Customizing HR practices for specific employee groups would seem beneficial. 
Supportive supervision was found to have the strongest effect on all three dimensions of innovative work behaviour. A sure way to improve innovative work behaviour by production workers is therefore to select and train supervisors such that they support employees in behaving innovatively. Further, organizations should be aware that perceptions of fairness in compensation can have a negative effect on employees' innovative work behaviour. We would argue that there should be some balance in terms of compensation system: employees should not be too dissatisfied with their compensation system since they might then feel the need to leave the organization (Park, Ofori-Dankwa, \& Bishop, 1994).

In our paper, we have argued that perceptions of HR practices have separate effects on three dimensions of innovative work behaviour (idea generation, idea championing, and idea application). The findings of our study support that overall argument and suggest that innovative work behaviour can be stimulated by the experienced presence of certain HR practices and by the experienced absence of others.

\section{References}

Amabile, T. M., \& Cheek, J. M. (1988). Microscopic and macroscopic creativity. Journal of Social and Biological Structures, 11(1), 57-60.

Amabile, T. M., Conti, R., Coon, H., Lazenby, J., \& Herron, M. (1996). Assessing the work environment for creativity. Academy of Management Journal, 39, 1154-1184.

Amabile, T. M., Hennessey, B. A., \& Grossman, B. S. (1986). Social influences on creativity: The effects of contracted-for rewards. Journal of Personality and Social Psychology, 50(1), 14-23.

Arad, S., Hanson, M. A., \& Schneider, R. J. (1997). A framework for the study of relationships between organizational characteristics and organizational innovation. Journal of Creative Behavior, 31(1), 42-58.

Arthur, J. B. (1994). Effects of human resource systems on manufacturing performance and turnover. Academy of Management Journal, 37(3), 670-687.

Ashford, S. J., \& Tsui, A. S. (1991). Self-regulation for managerial effectiveness: The role of active feedback seeking. Academy of Management Journal, 34(2), 251-280.

Axelrod, R. M. (1976). The structure of decision: Cognitive maps of political elites. Princeton, NJ: Princeton University Press.

Axtell, C. M., Holman, D. J., Unsworth, K. L., Wall, T. D., Waterson, P. E., \& Harrington, E. (2000). Shopfloor innovation: Facilitating the suggestion and implementation of ideas. Journal of Occupational and Organizational Psychology, 73(3), 265-285.

Baer, M. (2012). Putting creativity to work: The implementation of creative ideas in organizations. Academy of Management Journal, 55(5), 1102-1119.

Bartunek, J. M., \& Moch, M. K. (1994). Third-order organizational change and the Western mystical tradition. Journal of Organizational Change Management, 7(1), 24-41.

Bartunek, J. M., \& Ringuest, J. L. (1989). Enacting new perspectives through work activities during organizational transformation. Journal of Management Studies, 26(6), 541-560.

Basadur, M., Wakabayashi, M., \& Graen, G. B. (1990). Individual problem-solving styles and attitudes toward divergent thinking before and after training. Creativity Research Journal, 3(1), 22-32.

Basu, R., \& Green, S. G. (1997). Leader-member exchange and transformational leadership: An empirical examination of innovative behaviors in leader-members dyads. Journal of Applied Social Psychology, $27(6), 477-499$.

Beugelsdijk, S. (2008). Strategic human resource practices and product innovation. Organization Studies, 29(6), 821-847.

Blatter, M., Muehlemann, S., \& Schenker, S. (2012). The costs of hiring skilled workers. European Economic Review, 56(1), 20-35.

Blau, P. M. (1964). Exchange and power in social life. New York: Wiley. 
Boselie, P., Dietz, G., \& Boon, C. (2005). Commonalities and contradictions in HRM and performance research. Human Resource Management Journal, 15(3), 67-94.

Boselie, P., Hesselink, M., Paauwe, J., \& van der Wiele, T. (2001). Employee perceptions on commitment orientated work systems. Rotterdam, ERIM Workpaper. Retrieved from SSRN, http://ssrn.com/abstract=370862.

Bowen, D. E., \& Ostroff, C. (2004). Understanding HRM-firm performance linkages: The role of the "strength" of the HRM system. Academy of Management Review, 29(2), 203-221.

Brief, A. P. (1998). Attitudes in and around organizations. Thousand Oaks, CA: Sage.

Carmeli, A., \& Spreitzer, G. M. (2009). Trust, connectivity, and thriving: Implications for innovative behaviors at work. Journal of Creative Behavior, 43(3), 169-191.

Collins, C. J., \& Smith, K. G. (2006). Knowledge exchange and combination: The role of human resource practices in the performance of high-technology firms. Academy of Management Journal, 49(3), 544560.

Combs, J., Liu, Y., Hall, A., \& Ketchen, D. (2006). How much do high-performance work practices matter? A meta-analysis of their effects on organizational performance. Personnel Psychology, 59(3), 501528.

Cossette, P., \& Audet, M. (1992). Mapping of an idiosyncratic schema. Journal of Management Studies, 29(3), 325-347.

Cox, T. (1993). Cultural diversity in organizations: Theory, research and practice. San Francisco, CA: BerretKoehler.

Csikszentmihalyi, M. (1997). Creativity: Flow and the psychology of discovery and invention. New York: Harper Collins.

De Jong, J. P. J., \& Den Hartog, D. N. (2007). How leaders influence employees' innovative behaviour. European Journal of Innovation Management, 10(1), 41-64.

De Jong, J. P. J., \& Den Hartog, D. N. (2010). Measuring innovative work behavior. Creativity and Innovation Management, 19(1), 23-36.

De Leede, J., \& Looise, J. C. (2005). Innovation and HRM: Towards an integrated framework. Creativity and Innovation Management, 14(2), 108-117.

Deci, E. L., \& Ryan, R. M. (1985). Intrinsic motivation and self-determination in human behavior. New York: Plenum.

Delery, J. E., \& Doty, D. H. (1996). Modes of theorizing in strategic human resource management: Tests of universalistic, contingency, and configurational performance predictions. Academy of Management Journal, 39(4), 802-835.

Drazin, R., Glynn, M. A., \& Karanjian, R. K. (1999). Multilevel theorizing about creativity in organizations: A sensemaking perspective. Academy of Management Review, 24(2), 286-307.

Dul, J., Ceylan, C., \& Jaspers, F. (2011). Knowledge workers' creativity and the role of the physical work environment. Human Resource Management, 50(6), 715-734.

Dutton, J. E., \& Jackson, S. E. (1987). Categorizing strategic issues: Links to organizational action. Academy of Management Review, 12(1), 76-90.

Eisenberger, R., Armeli, S., \& Pretz, J. (1998). Can the promise of reward increase creativity? Journal of Personality and Social Psychology, 74(3), 704-714.

Evans, K., \& Waite, E. (2010). Stimulating the innovation potential of "routine" workers through workplace learning. Transfer: European Review of Labour and Research, 16(2), 243-258.

Farr, J. L. (1990) Individual innovation. In M. A. West \& J. L. Farr (Eds.), Innovation and creativity at work (pp. 1-13). Chichester: Wiley.

Folger, R. (1993). Justice, motivation, and performance beyond role requirements. Employee Responsibilities and Rights Journal, 6(3), 239-248.

Folger, R., \& Konovsky, M. A. (1989). Effects of procedural and distributive justice on reactions to pay raise decisions. Academy of Management Journal, 32(1), 115-130.

Frese, M., Teng, E., \& Wijnen, C. J. D. (1999). Helping to improve suggestion systems: Predictors of making suggestions in companies. Journal of Organizational Behavior, 20(7), 1139-1155.

Fyske, S. T., \& Taylor, F. E. (1991). Social cognition (2nd ed.). New York: McGraw-Hill.

Galbraith, J. R. (1982). Designing the innovating organization. Organizational Dynamics, 10(3), 5-25. 
Gioia, D. A., Donnellon, A., \& Sims, H. P. (1989). Communication and cognition in appraisal: A tale of two paradigms. Organization Studies, 10(4), 503-530.

Gonzalez-Alvarez, N., \& Nieto-Antolin, M. (2007). Appropriability of innovation results: An empirical study in Spanish manufacturing firms. Technovation, 27(5), 280-295.

Goodhew, G. W., Cammock, P. A., \& Hamilton, R. T. (2005). Managers' cognitive maps and intraorganizational performance differences. Journal of Managerial Psychology, 20(2), 124-136.

Gould-Williams, J., \& Davies, F. (2005). Using social exchange theory to predict the effects of HRM practice on employee outcomes. Public Management Review, 7(1), 1-24.

Gupta, A. K., \& Singhal, A. (1993). Managing human resources for innovation and creativity. Research Technology Management, 36(3), 41-48.

Guzzo, R. A., \& Noonan, K. A. (1994). Human resource practices as communications and the psychological contract. Human Resource Management, 33(3), 447-462.

Hair, J. F. Jr., Black, W. C., Babin, B. J., \& Anderson, R. E. (2010). Multivariate data analysis: A global perspective (7th ed.). Upper Saddle River, NJ: Prentice-Hall.

Hiltrop, J. M. (1996). A framework for diagnosing human resource management practices. European Management Journal, 14(3), 243-254.

Hodgkinson, G. P. (1997). The cognitive analysis of competitive structures: A review and critique. Human Relations, 50(6), 625-654.

Hodgkinson, G. P., \& Johnson, G. (1994). Exploring the mental models of competitive strategists: The case for a processual approach. Journal of Management Studies, 31(4), 525-551.

Hough, L. M., \& Schneider, R. J. (1996). Personality traits, taxonomies and applications in organizations. In M. Kevin (Ed.), Individual differences and behavior in organizations (pp. 31-88). San Francisco, CA: Jossey-Bass.

Howell, J. M., \& Higgins, C. A. (1990). Champions of technological innovation. Administrative Science Quarterly, 35(2), 317-341.

Howell, J. M., Shea, C. M., \& Higgins, C. A. (2005). Champions of product innovations: Defining, developing, and validating a measure of champion behavior. Journal of Business Venturing, 20(5), 641-661.

Høyrup, S. (2010). Employee-driven innovation and workplace learning: Basic concepts, approaches and themes. Transfer: European Review of Labour and Research, 16(2), 143-154.

Janssen, O. (2000). Job demands, perceptions of effort-reward fairness and innovative work behavior. Journal of Occupational and Organizational Psychology, 73, 287-302.

Janssen, O. (2004). How fairness perceptions make innovative behavior more or less stressful. Journal of Organizational Behavior, 25(2), 201-215.

Jenkins, M., \& Johnson, G. (1997). Linking managerial cognition and organizational performance: A preliminary investigation using causal maps. British Journal of Management, 8(s1), 577-590.

Jiang, J., Wang, S., \& Zhao, S. (2012). Does HRM facilitate employee creativity and organizational innovation? A study of Chinese firms. International Journal of Human Resource Management, 23(19), 40254047.

Jiménez-Jiménez, D., \& Sanz-Valle, R. (2008) Could HRM support organizational innovation? International Journal of Human Resource Management,19(7),1208-1221.

Judge, T. A., \& Cable, D. M. (1997). Applicant personality, organizational culture, and organization attraction. Personnel Psychology, 50(2), 359-394.

Kanter, R. M. (1988). When a thousand flowers bloom: Structural, collective, and social conditions for innovation in organization. Research in Organizational Behavior, 10, 169-211.

Kesting, P., \& Ulhøi, J. P. (2010). Employee-driven innovation: Extending the license to foster innovation. Management Decision, 48(1), 65-84.

Kleysen, R. F., \& Street, C. T. (2001). Toward a multi-dimensional measure of individual innovative behavior. Journal of Intellectual Capital, 2, 248-296.

Kuvaas, B. (2008). An exploration of how the employee-organization relationship affects the linkage between perception of developmental human resource practices and employee outcomes. Journal of Management Studies, 45(1), 1-25.

Kwon, K., Bae, J., \& Lawler, J. J. (2010). High commitment HR practices and top performers: Impacts on organizational commitment. Management International Review, 50(1), 57-80. 
Laukkanen, M. (1994). Comparative cause mapping of organizational cognitions. Organization Science, 5(3), 322-343.

Laursen, K., \& Foss, N.J. (2003). New human resource management practices, complementarities and the impact on innovation performance. Cambrigde Journal of Economics, 27(2), 243-263.

Lepak, D. P., \& Snell, S. A. (1999). The human resource architecture: Toward a theory of human capital allocation and development. Academy of Management Review, 24, 31-48.

Lepak, D. P., \& Snell, S. A. (2002). Examining the human resource architecture: The relationship among human capital, employment, and human resource configurations. Journal of Management, 28(4), $517-$ 543.

Locke, E., \& Latham, G. (1990). A theory of goal setting and task performance. Englewood Cliffs, NJ: Prentice Hall.

Locke, E. A., \& Latham, G. P. (2002). Building a practically useful theory of goal setting and task motivation. American Psychologist, 57(9), 705-717.

Lord, R. G., \& Maher, K. J. (1991). Cognitive theory in industrial and organizational psychology. In M. D. Dunnette \& M. H. Leatta (Eds.), Handbook of industrial and organizational psychology 2 (pp. 305-333). Palo Alto, CA: Consulting Psychologists Press.

Masterson, S. S. (2001). A trickle-down model of organizational justice: Relating employees' and customers' perceptions of and reactions to fairness. Journal of Applied Psychology, 86(4), 594-604.

McClean, E., \& Collins, C. J. (2011). High commitment HR practices, employee effort and firm performance: Investigating the effects of HR practices across employee groups within professional services firms. Human Resource Management, 50(3), 341-363.

Meglino, B. M., \& Ravlin, E. C. (1998). Individual values in organizations: Concepts, controversies, and research. Journal of Management, 24(3), 351-389.

Miles, R. E., \& Snow, C. C. (1984). Designing strategic human resources systems. Organizational Dynamics, 13(1), 36-52.

Milkovich, G., \& Newman, J. (1999). Compensation. Boston, MA: Irwin, McGraw-Hill.

Mumford, M. D. (2000). Managing creative people: Strategies and tactics for innovation. Human Resource Management Review, 10(3), 313-351.

Nishii, L.H., Lepak, D.P., \& Schneider, B. (2008). Employee attributions of the "why" of HR practices: Their effects on employee attitudes and behaviors, and customer satisfaction. Personnel Psychology, 61(3), 503-545.

O’Brien, R. M. (2007). A caution regarding rules of thumb for variance inflation factors. Quality \& Quantity, 41(5), 673-690.

Oldham, G. R., \& Cummings, A. (1996). Employee creativity: Personal and contextual factors at work. Academy of Management Journal, 39(3), 607-634.

Park, H. Y., Ofori-Dankwa, J., \& Bishop, D. R. (1994). Organizational and environmental determinants of functional and dysfunctional turnover: Practical and research implications. Human Relations, 47(3), 353-366.

Perry-Smith, J. E. (2006). Social yet creative: The role of social relationships in facilitating individual creativity. Academy of Management Journal, 49(1), 85-101.

Picchio, M., \& Van Ours, J. C. (2013). Retaining through training even for older workers. Economics of Education Review, 32(1), 29-48.

Podsakoff, P., \& Organ, D. (1986). Self-reports in organizational research: Problems and prospects. Journal of Management, 12(4), 531-544.

Reichstein, T., \& Salter, A. (2006). Investigating the sources of process innovation among UK manufacturing firms. Industrial and Corporate Change, 15(4), 653-682.

Remery, C., Henkens, K., Schippers, J., \& Ekamper, P. (2003). Managing an aging workforce and a tight labor market: Views held by Dutch employers. Population Research and Policy Review, 22(1), 21-40.

Rhoades Shanock, L., \& Eisenberger, R. (2006). When supervisors feel supported: Relationships with subordinates' perceived supervisor support, perceived organizational support and performance. Journal of Applied Psychology, 91(3), 689-695.

Rousseau, D. M. (2001). Schema, promise and mutuality: The building blocks of the psychological contract. Journal of Occupational and Organizational Psychology, 74(4), 511-541. 
Scott, S. G., \& Bruce, R. A. (1994). Determinants of innovative behavior: A path model of individual innovation in the workplace. Academy of Management Journal, 37(3), 580-607.

Scott, G., Leritz, L. E., \& Mumford, M. D. (2004). The effectiveness of creativity training: A quantitative review. Creativity Research Journal, 16(4), 361-388.

Shalley, C. E. (1995). Effects of coaction, expected evaluation, and goal setting on creativity and productivity. Academy of Management Journal, 38(2), 483-503.

Shalley, C. E., \& Gilson, L. L. (2004). What leaders need to know: A review of social and contextual factors that can foster or hinder creativity. Leadership Quarterly, 15(1), 33-53.

Shalley, C. E., Gilson, L. L., \& Blum, T. C. (2009). Interactive effects of growth need strength, work context, and job complexity on self-reported creative performance. Academy of Management Journal, 52(3), 489-505.

Shipton, H., West, M.A., Dawson, J., Birdi, K., \& Patterson, M. (2006). HRM as a predictor of innovation. Human Resource Management Journal, 16(1), 3-27.

Sonnenberg, M., Van Zijderveld, V., \& Brinks, M. (2014). The role of talent-perception incongruence in effective talent management. Journal of World Business, 49(2), 272-280.

Stevens, G. A., \& Burley, J. (1997). 3,000 raw ideas equal 1 commercial success! Research-Technology Management, 40(3), 16-27.

Taylor, A., \& Greve, H. R. (2006). Superman or the Fantastic Four? Knowledge combination and experience in innovative teams. Academy of Management Journal, 49(4), 723-740.

Thomas, J. B., Clark, S. M., \& Gioia, D. A. (1993). Strategic sensemaking and organizational performance: Linkages among scanning, interpretation, action, and outcomes. Academy of Management Journal, 36(2), 239-270.

Thompson, M., \& Heron, P. (2006). Relational quality and innovative performance in R\&D based science and technology firms. Human Resource Management Journal, 16(1), $28-47$.

Wallace, J. E. (1995). Corporatist control and organizational commitment among professionals: The case of lawyers working in law firms. Social Forces, 73(3), 811-840.

Wanberg, C. R., \& Banas, J. T. (2000). Predictors and outcomes of openness to changes in a reorganizing workplace. Journal of Applied Psychology, 85(1), 132-142.

Way, S. E. (2002). High performance work systems and intermediate indicators of firm performance within the US small business sector. Journal of Management, 28(6), 765-785.

Weigelt, C., \& Sarkar, M.B. (2012). Performance implications of outsourcing for technological innovations: Managing the efficiency and adaptability trade-off. Strategic Management Journal, 33(2), 189-216.

Weick, K., Sutcliffe, K. M., \& Obstfeld, D. (2005). Organizing and process of sensemaking. Organization Science, 16(4), 409-421.

West, M. A. (2002). Ideas are ten a penny: It's team implementation not idea generation that counts. Applied Psychology, 51(3), 411-424.

Woodman, R. W., Sawyer, J. E., \& Griffin, R. W. (1993). Toward a theory of organizational creativity. Academy of Management Review, 18(2), 293-321.

Wright, P. M., \& Nishii, L. (2006). Strategic HRM and organizational behavior: Integrating multiple levels of analysis. Working paper 06-05. Ithaca, NY: CAHRS Cornell University.

Yukl, G., Wall, S., \& Lepsinger, R. (1990). Preliminary report on validation of the managerial practices survey. In K. E. Clark \& M. B. Clark (Eds.), Measures of leadership (pp. 223-238). West Orange, NJ: Leadership Library of America.

Zhou, Y., Zhang, Y., \& Montoro-Sanchez, A. (2011). Utilitarianism or romanticism: The effect of rewards on employees' innovative behaviour. International Journal of Manpower, 32(1), 81-98. 